Jurnal Pendidikan Bahasa Inggris Proficiency, Vol 4 No 1 Jan 2022

\title{
ONLINE ENGLISH TEACHING BY USING GOOGLE CLASSROOM AND ITS CHALLENGES DURING COVID-19 PANDEMIC AT SMAN 1 GEDEG MOJOKERTO
}

\author{
Erik Setiawan, Entusiastik \\ eriksetiawan852@gmail.com, entusiastik@uniska-kediri.ac.id
}

\begin{abstract}
This reseach aimed 1) to know the teachers and students carry out online English teaching and learning, 2) to know the challenges of online English teaching and learning, and 3) to know about how the teacher and students solve the challenges during carrying out online English teaching and learning of analytical exposition text during the Covid-19 pandemic. This research used a qualitative approach. The researcher took 2 classes (IPA-1 \& IPS-2) as sample. In the data collection technique, researcher used observation, interview, documentation, and questionnaire. The data analysis in this research used flow model data analysis by Miles and Huberman: checking the validity of the data with credibility, transferability, dependability, confirmability. The results showed that 1) The implementation of Online English teaching and learning was good, 2) Both of teachers had the same challenges such as time management, giving appropriate the material, and also collecting the task from the students, and 3) Both of the teachers had the same solution such as giving long time for the students to learn in Google Classroom, giving the additional material from the internet or gave the students opportunity to private chat by WhatsApp or Google Classroom, and giving the students longer time to collect the task till the following day. After finding the result, it is expected to be able to do better research as a reference to improve in educational research
\end{abstract}

Key word: Google Classroom, online teaching and learning, writing,

\section{INTRODUCTION}

In the early year of 2020, the new kind of virus appalled and shocked everyone worldwide. The virus was mentioned from Wuhan. China has infected almost all countries globally (Huang et al., 2020). The cause of Coronavirus diseases 2019 (COVID-19) is Severe Acute Respiratory Syndrome Coronavirus-2 (SARS CoV-2). Joko Widodo as the President of Indonesia Widodo announced that two Indonesian people had infected SARS CoV-2 on the 2nd of March 2020 and on the 13th of May 2020, there are 15.438 positive cases in Indonesia with details of 3.287 recovered, 1.028 passed away, and the other still doing treatment (Gugus Tugas Percepepatan Penanganan Covid-19, 2020). This Cornovirus has an impact on almost all aspects such as economy, medical, and special education.

Furthermore, teaching activities is one of many aspects of education that has been impacted by the Covid-19 pandemic. However, the teacher must go teaching the students during the Covid-19 pandemic. The teacher should have a solution to teach the students. It will be a new experience for the students and the teachers 
because they do teaching activities with no meeting. Furthermore, Wong (2020) says that online learning is interactive learning. Students will automatically get input from their learning activities with assistance such as tablets, smartphones, laptops, and computers that require an internet connection and the availability of online learning resources and materials. Also, Panigrahi (2016) says that online learning uses telecommunications to convey information and learning materials so that this type of learning does not use learning materials in the form of printed books.

Meanwhile, According to Rahmawati (2017), the hardest skill in learning English is writing second language learners' writing skills. Writing learning in senior high school aims to properly use words, vocabulary, grammar, spelling, and punctuation. The students are competent to express their ideas in written form by using language variations that are appropriate and accurate in interactions or monologues such as descriptive, recount, narrative, procedure, report, exposition text, especially analytical exposition text was taught in the eleventh class at the first semester. In the eleventh grade at senior high school, the writing's purpose is to organize oral and written analytical exposition text, short and simple, relevant to the actual issues (Kemendikbud, 2013). In teaching exposition analytic text, eleventh-grade students are targeted to write simple analytical exposition text correctly using the online learning method.

One of the schools which did online teaching and learning was SMAN 1 Gedeg Mojokerto. This school instructed the teachers to work from home, and the students learn from home. The school carried out online teaching and learning from the 24th of March 2020 till now. The researcher chose this school because this school applied for the emergency curriculum 2013 during the Covid-19 pandemic, which is this school just applies only two materials in one semester. And also, the main learning material system platform used by the teachers is Google Classroom. Meanwhile, they also use several other tools, such as what apps to support their teaching and learning activities.

Based on the condition due to the Covid-19 pandemic and the government's policy to carry out online learning, it caused the teachers to teach from home, and the students learn from home. Therefore, the researcher was in a very big curiosity to research the title "Online English Teaching By Using Google Classroom and its Challenges during Covid-19 Pandemic at SMAN 1 Gedeg Mojokert"

\section{METHOD}

This research used the descriptive qualitative method. It is to find the right way to implement an overall learning process (Sugiyono, 2011). This learning method uses google classroom in teaching and learning during the covid-19 pandemic. This sample was 67 students of tenth grade at SMAN 1 Gedeg, Mojokerto from 2 classes IPS2 and IPA1. Data collection was carried out by interview, field observation and documentation. The data is analyzed, contextual data includes three procedures such as: reduction, data presentation, and drawing conclusions and verification. Furthermore, The data analysis in this research used flow model data analysis by Miles and Huberman: checking the validity of the data with credibility, transferability, dependability, confirmability. 
Jurnal Pendidikan Bahasa Inggris Proficiency, Vol 4 No 1 Jan 2022

\section{RESEARCH FINDING \\ The Implementation of Online English Teaching and Learning}

In carrying out the research, the researcher observed learning activities through Google Classroom and interviewed English teachers and students of SMAN 1 Gedeg, Mojokerto. From the results of observations and interviews, it is known that the results of the implementation of Google Classroom learning for Analytical Exposition Text material have been running during the COVID-19 pandemic. The implementation of the Google Classroom learning material from the Analytical Exposition Text material was carried out for three meetings. Each meeting was 90 minutes ( $2 \times 45$ minutes), and the class was held once a week for students of IPS-2 and IPA-1.

The conditions for implementing teaching and learning both of classes during the COVID-19 pandemic are not much different from face-to-face teaching and learning, based on observations and interviews of students and teachers (Ibu Arina and Ibu Tari) have good interacting with each other when the teaching and learning process on the Analytical Exposition material, this implementation included preliminary activities, main activities, and closing activities.

1. Opening of Teaching: Based on the interview on 7th August 2020 with $\mathrm{Bu}$ Arina as the teacher of XI IPS2. There were six questions for getting information on the teaching process. The first question was, "What did you do at the beginning of learning using Google Classroom for class XI IPS2 students?" Bu Arina said in an interview that at the beginning of teaching and learning, the teacher has one meeting to explain the media and how to use Google Classroom as the platform for online learning. Here, the statement as follows:

$\mathrm{Bu}$ Arina said, "So, before online learning, we were allowed to enter one meeting, so that's where we explained about what we use for online learning activities from Google Classroom. So, there we give them the code."

Meanwhile, Bu Tari asked one of the students in the class to be a coordinator of the class to coordinate about media and online learning. She proved it.

Bu Tari said, "Before I enter Google Classroom there must be one child to be the coordinator, and I explain about Google Classroom then if it is certain, the coordinator explains to the class group about Google Classroom then I create a group in Google Classroom and share giving the link and the Google Class Group code."

At the beginning of the class by Google Classroom from Bu Arina, the result showed that she opened the class by greeting the student and asked the students to mention the name as the attendance. Bu Arina said, "I start teaching by greeting, then ask the student to fill the attendance list in Google Classroom by click "HADIR" And at the beginning of the class from Bu Lestari. She opened the class by greeting in the Google Classroom, and she gave a link to Google form as the attendance list, and the students fill the link.

2. Main Activities: The material is the content of the lessons given by teachers to students during the teaching and learning process. In teaching preparation, the 
teacher should have prepared the material to be taught to students. Based on observations and interviews with the first teacher (Bu Arina) in giving the material, the teacher has conveyed the material.

Based on the interview and the observation from the first meeting, She reminded students to fill in the attendance list. First, she explained the exposition analysis text in the form of PPT, she gave students a break to read and understand the material in the PPT, she gave time to ask questions, she gave instructions to work on Questions in PPT, she gave the motivation to work on the questions in the PPT, she gave responses to students' questions in the comments column, and she provided additional notes regarding the material presented.

In a second meeting, she explained the analytical exposition text in Google Classroom, she gave the analytical Exposition text "The importance of English Language," she asked students to analyze the general structure of the exposition text, she asked students to find five sentences in the text that used the simple present, she provided an example of Outline analytical exposition text, she asked students to make Outline analytical exposition text. The last, she asked students to choose one of the titles to outline (1.Bullying at school, 2. Protecting ourselves from Coronavirus, 3.Hadphone for studying ).

In a third meeting, the students were asked to make the Exposition Analysis Text, they were asked to make the Exposition Analysis text from the previously made outline, and the last, they were asked to submit the writing assignment of the exposition analysis text in Google Classroom.

Besides, based on the results of observations, the main activities of online English teaching by Google Classroom from Bu Arina showed that she used books, material from the internet, and material from the agreement with teachers in Mojokerto source of teaching material. Also, she gave the material by giving text. Furthermore, she taught the students by giving documents as media that was taken by the book. She also does not have a special teaching method in Google Classroom because of the limited time in teaching online by Google Classroom.

Based on observations and interviews with the first teacher (Bu Tari) in giving the material, she has conveyed the material. From the interview and the observation from the first meeting, she asked students to check the exposition analysis text's title that the student has made. She asked students to make an Exposition Analysis Text according to the title that has been previously made, and last, she asked students to collect the results of the exposition analysis text assignment in Google Classroom.

In a second meeting, the teacher asked students to review the material that has been given, she asked students to create a title for analytical exposure text, she asked to submit the title to the class coordinator, and last she asked the class coordinator to upload in the Google Classroom.

In the third meeting, the teacher asked students to check the title of the exposition analysis text that students have made. She asks students to make the Exposition Analysis Text according to the title that has been previously made. The last, she asks students to collect the results of the exposition analysis text assignment in Google Classroom. 
The researcher also made the data of observation guideline for the teacher, $\mathrm{Bu}$ Arina, and $\mathrm{Bu}$ Lestari. The teachers gave the tutorial on how to use Google Classroom, instructed the students to be ready for joining the class according to the schedule, or before the class was started, the teacher gave instruction for all the students to log in to Google Classroom, gave attendance list for the students at the beginning of the class, gave material and the task in Google Classroom, gave instructions to do the task that was shared in Google Classroom, arranged the deadline of collecting the task by Google Classroom, gave scoring to the task that has been collected in Google Classroom, and the last sent information about the learning process at that day and also for the next meeting.

3. Closing of Teaching: Based on the interview result, the main activities of online English teaching by Google Classroom from Bu Arina showed that she used books, material from the internet, youtube, and material from the agreement with teachers in Mojokerto as the source of teaching material. Also, she delivered the material by giving text and the video related to the material because it made the students interested in learning English by Google Classroom. Furthermore, she taught the students by giving video and document as media taken by the book. She also does not have a special teaching method in Google Classroom because of the limited time in teaching online by Google Classroom. She did not give any closing for the closing of class because she just gave at the opening class, such as greeting and motivation at the beginning of class. Here, the statement as follows:

"Well, here for the closing is nothing. So, I only clicked on the forum there, starting from the opening greetings and happy learning and so on in the forum at the beginning of the lesson, and don't forget to fill in the attendance list at the beginning."

Furthermore, based on an interview with Bu Lestari, she said that the material given to the students from the internet is related to the material. She shares the link of material to the students by Google Classroom. Then the students learned by themselves from the link. The teacher uses a smartphone in teaching the students by Google Classroom. And also, she does not have a special teaching method by Google Classroom because teaching online was more simple than conventional teaching, but the students must be more creative and more diligent. At the closing of the class, she just gave an assessment and explained the next material discussed in the next meeting. Here, the statement as follows:

"Usually, if I finish after I give an assignment, then I explain the next meeting."

Based on the explanation above, it can be concluded the teacher only close the teaching process by greeting. According to the students' interview, by giving a questionnaire to the students of IPS 2 and IPA1, 28 students gave the response. From the responses, the students were able to follow the lesson well. They understand how to use Google Classroom, they also have had Google Classroom account, they already have a handphone or laptop for learning and joining the class, they also have internet quotas for joining the class. And the students have to join the class according to the schedule that was given by the teacher, and they were easy to send their duty in the form of a picture. 
Furthermore, the observation guideline for the students' learning from 3 meetings was done by the researcher to find information about students' learning. The result showed that the students have understood how to use Google Classroom, they have already their smartphone, they were easy to log in to Google Classroom, they were easy to download the material that was given by the teacher in Google Classroom, they were able to fill the attendance list in Google Classroom, they were motivated for learning in Google Classroom, they were easy to finish the task in Google Classroom, they were able to send the task in Google Classroom, they were able to communicate and discuss with the teacher by Google Classroom, and the last the students were able to post the information in Google Classroom.

Base on the explanation above, it can be concluded that all of the students could join the learning process well by using Google Classroom from the information of students' interviews. Also, From the observation from 3 meetings was done by the researcher. The students were able to join and follow the instruction from the students very well.

Assessment of learning outcomes is carried out to determine the student's understanding and measure students' ability to understand the material. The researcher described the student learning outcomes in learning Google Classroom in the COVID-19 pandemic era toward analytical exposition text material. As the results information of the interview with $\mathrm{Bu}$. Arina as the teacher IPS 1 as follows: "Generally, the results are good for achieving KKM. Classically, it has reached the KKM for the Analytical Exposition Text material," and Based on the results of the interview with Bu Lestari as IPA-2, it has similarities with the results of the interview with $\mathrm{Bu}$ Arina as IPS-1 as follows: "Some students can follow and understand the material well and they have reached the KKM." All of them have passed the minimum completeness criteria (KKM) With minimum completeness criteria (KKM) English subject at SMAN 1 Gedeg school year 2020/2021 $\geq 74$, especially in the material of analytical exposition text.

Based on the evaluation results after the end of the material on IPS-1 and IPA2 class students. The students have passed the minimum completeness criteria (KKM).

\section{The Teacher and Students Challenges for Teaching and Learning by Google Classroom during the Covid-19 Pandemic}

Based on the data interview from $\mathrm{Bu}$ Arina, there were five questions for getting information about the challenge of teaching. The first question was, "what challenges do you face when you teach by Google Classroom?" Bu Arina said the first challenge was the time to deliver the material. Although the teacher gave the class schedule, the students could open the task in Google Classroom at noon or evening because sometimes the students could not join the class on time, and the teacher could not control students directly. The next, it about the question and answer about the material between students to the teacher because most of the students were passive, so the teacher could not see the students' activeness, but she also gave additional material from, website or file quotation consists of material. So, the students could do experiments and understanding according to instruction there. Here, the statement as follows: 
"The first is the delivery time, even if there is a schedule. But if I deliver it this morning, it's up to the children to open it when, but in the classroom, I have given it what time it will arrive. So they are lazy about time, so students cannot be in school from this hour until this time is right because we cannot supervise it directly. The second one is frankly the question and answer problem regarding the material and so on, students to teachers, because our students tend to be passive, and if they are active, they usually have to be pressed first. They are less visible here. And also, I provide additional material from youtube, website, or file links containing material. So students can experiment and understand according to the instructions there."

The second question was, "what challenge do you face when you deliver or explain the lesson to the students by Google Classroom?" Bu Arina answered that when she delivered the lesson, the student seldom asked about the explanation, although she asked them to ask when they had a problem with the material. Here, the statement as follows:

"Here, at the time of delivery of the material, children rarely ask questions about material difficulties even though they have been asked to ask questions about difficulties."

The third question was, "what difficulties were the students faced in learning by Google Classroom?" Bu Arina answered that the main difficulties were about internet quotas and limited the internet quotas, and sometimes the task would be collected the following day. And also, there was a video with high capacity, which is difficult to send. The Google drive of the students was full, which made it difficult to send the task. Here, the statement as follows:

"The main difficulty is about the quota and running out of data packages, and sometimes it is collected the next day. And sometimes, there are videos with a large capacity that is difficult to send. Sometimes there are also times when the drive is full, and the student cannot deliver."

The next was an interview with Bu Lestari as the teacher for XI IPA1. The first question was "what challenges do you face when you teach by Google Classroom?" she answered that the duration of teaching and learning in Google Classroom was limited because sometimes the student was not on time to join the class and also the student joins the class when the class would end. The statement from Bu Lestari was:

"The duration, the duration for teaching online cannot be as usual. Sometimes some students enter the Google Classroom not on time; sometimes, some students are about to run out of study time but have just entered Google Classroom."

The second question was, "what challenge do you face when you deliver or explain the lesson to the students by Google Classroom?". She said that many students did not understand. They really join in Google Classroom, or just give attendance, then they sleep.

"The challenge is, some students do not understand. We also don't know that they are online or that they are present, and then they are left to sleep."

The third question was, "What are the teachers' challenges when the students got difficulties in the learning process?". She answered that the students have 
difficulty having internet quotas because they have to study online every day. The statement as follow:

"As they have said, children struggle to have internet quotas because they have to be online every day."

Meanwhile, based on the questionnaire that was given to the students' XI IPS2 and IPA1. The questions were about the challenges for learning English by Google Classroom. Of 68 students, only 13 students gave a response. They have two various answers. 10 students have a problem with a signal. They were difficult to get signals when they carried out online learning, and also, if there were prams of electricity, the signal was lost, and they would be late in collecting the task. These were one of the statements :

"The problem is more to the signal. Sometimes if there is a power cut, the signal also off / disappears. And as a result of collecting the assignments late."

Then, three students gave responses. The reason was the problem with internet quotas. They got the internet from school, but the quotas are only for learning applications include Google Classroom, and they could not browse on the internet. These were the statement :

"Yes, but can only be used to open assignments in Google Classroom or what is commonly known as a learning quota, and there is no internet quota. If you have to upload your assignments to Google Drive, what is used to upload files/photos on Google Drive is the internet quota, while what is given by the school/government only contains the learning quota. The result is useless if you get a quote, but it can only be used to open tasks. To collect assignments, I use my own quota. So I did not use quotas and from school. Not out of disrespect, but it could not help to collect the assignments assigned."

Based on the explanation above, it can be concluded that the teachers' challenges such as time management, giving the material, and also collecting the task from the students. And the students' challenges, such as difficulty to get the signal and internet quotas.

\section{The Strategies for Coping the Teachers and Students Challenges}

Based on the data interview from the $\mathrm{Bu}$ Arina, there were three questions for getting information about the problem solution of teaching. The first question was, "How do you solve the problem when you are teaching online by Google Classroom (The problem of giving material)?". The solution was giving more time to understand the materials by themselves, and also she gave additional material from the website or file links containing instructions. So, students can do experiments, and students follow the instructions there. Here, the statement as follows:

"So for the material, I don't know what time the children open, so I limit it to at least one day the children have learned my material. I also provide material from youtube, website, or file links with instructions. So students can do experiments, and students follow the instructions there. Indeed, I will tell them if there got difficulties in collecting the task, please share via Google Classroom or WhatsApp." 
The second question was, "How do you solve the problem when the students are getting problems in understanding the material?" Bu Arina answered that If the students were getting a problem understanding the materials, they could ask private chat in WhatsApp or Google Classroom. Here, the statement as follows:

"If students have problems understanding the material, they can ask questions via a private chat on WhatAppss or Google Classroom."

The third question was, "How do you solve the problem when the students are getting problems in collecting their task?" Bu Arina answered that If the students were getting a problem to collect the task, they could also send the task by private message on WhatsApp, or students can come directly to the school.

"If students have problems submitting assignments, they can also send assignments via private message on WhatApps, or students can come directly to the school."

Based on the data interview from Bu Lestari, There were three questions for getting information on the problem solution of teaching. The first question was, "How do you solve the problem when you are teaching online by Google Classroom (The problem of giving material)?". The solution is to find materials that match the syllabus via the internet. Here, the statement as follows:

"The solution is to find materials that match the syllabus via the internet."

The second question was, "How do you solve the problem when the students are getting problems in understanding the material?" Bu Lestari answered that The solution is to provide additional material from the linked material from the internet to better understand the material I provide. Here, the statement as follows:

"The solution is to provide additional material from link material from the internet so that students understand better the material I provide."

The third question was, "How do you solve the problem when the students are getting problems in collecting their task?" Bu Lestari answered that if the students have problems submitting assignments or cannot. The teacher asked the students to contact via WhatApps. Here, the statement as follows:

"Usually, if a student has a problem submitting assignments, I can't ask them to contact them via WhatsApp. If I don't have it, like yesterday, there were those whose smartphones were broken. I asked them to handwrite them, and then I found them at school or through the class coordinator and class coordinator to meet me. Can chat privately via WhatsApp."

Based on the explanation above, it can be concluded that the teachers have the best solution for solving the student's problem in teaching online by Google Classroom.

Meanwhile, from the questionnaire, the students have various answers to cope with the problem. When they got a problem getting the signal, they looked for wifi in the cafe, and also they looked for an easy place to get the signal. These were the statement :

"Looking for an easy place to find signals, ask the teacher in person, and look for understanding like on youtube, etc." 
Jurnal Pendidikan Bahasa Inggris Proficiency, Vol 4 No 1 Jan 2022

Furthermore, when the students have a problem with internet quotas, they ask their parent's internet quotas or the students ware bought the internet quotas from their parents. These were the statement :

"Use the hotspot from the parent's cellphone. Or buy a new quota when the quota runs out."

Based on the explanation above, the teacher has the solution for the challenges such as the teacher gave longe time for the students to learn in Google Classroom, gave the additional material from the internet or gave the students opportunity to private chat by WhatsApp or Google Classroom, gave the students longer time to collect the task till the following day.

\section{DISCUSSION}

Based on the result above, these results are by the results of research obtained by Sukmawati \& Nensia (2019), which obtained results that the use of Google Classroom can improve the ability of students in the English language education study program (ELT), especially in terms of understanding the material taught. Students and teachers can create interactions, even if only in virtual interactions through Google Classroom. Students also find it easier to find and obtain teaching materials that have been uploaded by the teacher through Google Classroom.

The same results were also obtained by Alim et al. (2019) in his research, which states that the use of Google Classroom can improve communication and collaboration skills between students. The use of Google Classroom also helps students to increase their awareness in adopting new technology. This is due to the rapid development of technology, as well as students who are unable to adapt. Well, it is feared that there will be a backward technology Creative and innovation when getting technology-based learning, especially using Google Classroom.

Accordance with the results obtained by Sepyanda (2018) shows that students feel happy and enthusiastic in using Google Classroom in studying the material. According to Pakpahan \& Fitriani (2020), the learning process can run well with the presence of information technology that has developed rapidly at this time, including e-learning, Google Classroom, WhatsApp, zoom, and other information media, as well as internet networks that can connect teachers and students so that the teaching and learning process can run well as it should be even amid the Covid19 pandemic.

Furthermore, prospective teachers must prepare themselves to face the demands of the times with the rapid advancement of technology in this industrial 4.0 era. Prospective teachers who are students majoring in English Education are expected to be better prepared to prepare for face-to-face learning and online learning both in terms of learning media and from material and mental readiness. With the learning experience they have during online learning, these prospective teacher students are expected to become future teacher candidates professional one. According to Sukardi \& Rahmat (2019), one way to face the challenges of the industrial era 4.0 is by providing a learning experience not only in the classroom but even more so because learning at this time requires students not only to focus face-to-face but also demanded to make more use of technology. 
Jurnal Pendidikan Bahasa Inggris Proficiency, Vol 4 No 1 Jan 2022

\section{CONCLUTION AND SUGGESTION}

From the research online English teaching activities in XI IPS2 and IPA1 at SMAN 1 Gedeg Mojokerto, the researcher concluded that the Preparation for teaching and learning was the teachers were ready for teaching English by Google Classroom and also the students. For the teaching process, they have different teaching process. At the beginning of the teaching, Bu Arina gave the material such as text and PowerPoint, but Bu Lestari gave the link of material that she took from the internet. Teaching and learning were good not only IPA1 but also IPS 2 because all the students passed the standard minimum score that was $<74$.

During the teaching process, $\mathrm{Bu}$ Arina and $\mathrm{Bu}$ Lestari had the same challenges, such as the time for teaching is limited because teaching online needed more time because the teachers could not control the students directly like in the classroom. The teachers felt it difficult to control the students because they did not know whether they would join the class or just filled the attendance list. Furthermore, the teacher could not get the material for online teaching from school; instead, the teachers have to look for the appropriate material. So, there are no different challenges in both $\mathrm{Bu}$ Arina and Bu Lestari.

The first challenge was looking for the appropriate material for the students. Both Bu Arina and Bu Lestari have the same solution for solving it. They looked for the material from the internet, such as the linked website. The second challenge was time management. They gave the students a long time to collect the task if they got problems in sending tasks. Then, giving an understanding to the student who did not understand was asked the student to chat personally by WhatsApp.

\section{REFERENCES}

Alim, N., Linda, W., Gunawan, F., \& Saad, M. S. M. (2019). The Effectiveness Of Google Classroom As An Instructional Media: A Case Of State Islamic Institute Of Kendari, Indonesia. Humanities And Social Sciences Reviews, 7(2), 240-246.

Huang, R., Tlili, A., Chang, T. W., Zhang, X., Nascimbeni, F., \& Burgos, D. (2020). Disrupted Classes, Undisrupted Learning During Covid-19 Outbreak In China: Application Of Open Educational Practices And Resources. Smart Learning Environments, 7(1), 1-15.

Kemendikbud. (2013). Peraturan Pemerintanh Nomor 59 Tahun 2014 Tentang Kurikulum 2013 Sekolah Menengah Atas (Sma)/Madrasah Aliyah (Ma).

Pakpahan, R., \& Fitriani, Y. (2020). Analisa Pemanfaatan Teknologi Informasi Dalam Pembelajaran Jarak Jauh Di Tengah Pandemi Virus Corona Covid-19. Journal Of Information System, Applied, Management, Accounting And Research, 4(2),30-36.

Panigrahi, R., Srivastava, P. R., \& Sharma, D. (2018). Online Learning: Adoption, Continuance, And Learning Outcome-A Review Of Literature. International Journal Of Information Management, 43, 1-14.

Rahmawati, O. I. (2017). Think-Pair-Share: A Tecnique To Enhance Students'writing Skill. Jurnal Pendidikan Edutama, 4(1), 49-57. 
Jurnal Pendidikan Bahasa Inggris Proficiency, Vol 4 No 1 Jan 2022

Sepyanda, M. (2018). Students' Attitude Toward The Use Of Google Classroom On Translation Subject In English Department Of Fkip Ummy Solok. English Language Teaching And Research, 2(1), 180-188.

Sukardi, S., \& Rahmat, M. H. (2019). Pencapaian Hasil Belajar Teori Kejuruan Ditinjau Dari Persepsi Mahasiswa Pada Pembelajaran Online. Jurnal Dinamika Vokasional Teknik Mesin, 4(2), 111-116.

Sugiyono. (2011). Metode Penelitian Kuantitatif, Kualitatif, dan R\&D. Bandung: Alfabeta.

Sukmawati, \& Nensia. (2019). The Role Of Google Classroom In Elt. International Journal For Educational And Vocational Studies, 1(2), 142-145.

Wong, R. (2020). When No One Can Go To School: Does Online Learning Meet Students' Basic Learning Needs. Interactive Learning Environments, 1-17. 